\section{Ontogenesis of the Somatic Embryogenesis of Habanero Pepper (Capsicum chinense Jacq.)}

\author{
Nancy Santana-Buzzy ${ }^{1}$, Guadalupe López-Puc, Adriana Canto-Flick, \\ Felipe Barredo-Pool, Eduardo Balam-Uc, Susana Avilés-Viñas, \\ Daniela Solís-Marroquín, Carlos Lecona-Guzmán, \\ Jericó Jabín Bello-Bello, Eunice Gómez-Uc, \\ and Javier O. Mijangos-Cortés \\ Unidad de Bioquímica y Biológica Molecular de Plantas, Centro de \\ Investigación Cientifica de Yucatán, Calle 43 No. 130, Chuburná de \\ Hidalgo, Mérida, Yucatán, 97200, México
}

Additional index words. provascular cells, histodifferentiation, abnormalities, recalcitrance, histological analysis

\begin{abstract}
The ontogenesis of direct high-frequency somatic embryogenesis of $C$. chinense induced from hypocotyl was characterized through a histological analysis of the different phases in the histodifferentiation process during the development of the somatic embryo. The anatomical analysis was carried out since the hypocotyl segments were placed in the culture medium until 45 days of culture. The somatic embryos were induced and maintained in Murashige and Skoog medium supplemented with 2,4-dichlorophenoxyacetic acid $(9.5 \mu \mathrm{M})$. Samples of tissues and organs were taken every $24 \mathrm{~h}$, fixed in formalin acetic alcohol, and embedded in plastic resin. They were cut into serial sections $(5 \mu \mathrm{m})$ and stained with toluidine blue. The analysis revealed that the proembryogenic cells originated just from provascular hypocotyl cells. Provascular cells acquired the embryogenic competence $48 \mathrm{~h}$ after induction and an intense mitotic division was observed and embryogenic structures were generated first along the vascular strands, which subsequently evolved into somatic embryos. After 2 weeks, there were observed embryos at different stages of development (preglobular, globular, heart-shaped, torpedo-shaped, and cotyledonary). This is the first report dealing with the ontogenesis of the direct somatic embryogenesis of $C$. chinense, and it is the most complete histological characterization carried out on somatic embryogenesis in the Capsicum genus to date.
\end{abstract}

Somatic embryogenesis can be described as the process through which haploid or diploid somatic cells develop into different kind of plants through the characteristic embryological stages without fusion of gametes (Williams and Maheswaran, 1986). This phenomenon has been observed in tissue culture of several angiosperm and gymnosperm plant species. The anatomy of somatic embryos has been presented by many authors (Auboiron et al., 1990; Decout et al., 1994; Gill and Saxena, 1993; Suhasini et al., 1994). However, few studies have characterized the different ontogenetic stages of these embryos (Fransz and Schel, 1991; Toonen et al., 1994; Yeung et al., 1996).

The somatic embryogenesis, besides being an important pathway for plant regeneration from cell culture systems and a commonly used method in large-scale production of plants and synthetic seeds (Stuart et al., 1987), is also an excellent morphoge-

Received for publication 25 June 2008. Accepted for publication 1 Nov. 2008.

This research was supported by CONACYT and SINAREFI.

${ }^{1}$ To whom reprint requests should be addressed; e-mail buzzy@cicy.mx. netic system, which allows the study of differentiation processes. Somatic embryos can easily be obtained from an embryogenic cellular line maintained under controlled external conditions such as medium composition, growth regulators, and light. Halperin (1966) was the first one who demonstrated that somatic embryos arose from particular cluster of cells, named proembryogenic masses, which, in turn, originated from single cells. However, the most important, but also the least understood, aspect of somatic embryogenesis is the transition of somatic cells into cells capable of forming an embryo (De Jong et al., 1993).

Regarding the origin of somatic embryos, the main aspects for researchers are still: the primary tissues (Aleman et al., 1996; Lee et al., 1997; Puigderrajols et al., 1996), the unicellular or multicellular origin (Alemanto et al., 1996; Lee et al., 1997; Loiseau et al., 1998; Marin-Hernández et al., 1998; Nonohay et al., 1999; Puigderrajols et al., 1996), cytological aspects of the competent cells (Alemano et al., 1996; Lu and Vasil, 1985; Menéndez-Yufaá and García de García, 1997), and histochemistry of the somatic embryos through its formation and development, particularly concerning starch, proteins, and polyphenols (Alemano et al., 1996; Garin et al., 1997; Goh et al., 1999; Loiseau et al., 1998; Marin-Hernández et al., 1998; Navarro et al., 1997; Svobodová et al., 1999). The extensive literature in this field has also considered the histological aspects of the initiation and development of somatic embryos, although several fundamental aspects of the process remain unclear or appear to differ among the systematic groups (Benelli et al., 2001). However, as knowledge increases on the genesis and evolution of somatic embryos, the level of empiricism will diminish and the ability to reproduce this complex process will be enhanced.

Histological studies to describe the development of somatic embryos have been done on Quercus robur (Zegzouti et al., 2001), Olea europea (Benelli et al., 2001), Safflower (Mandal and Gupta, 2003), Solanum tuberosum (Kumar and Millam, 2004), Feijoa sellowiiana (Cangahuala-Inocente et al., 2004), Schlumbergera truncata (Al-Dein et al., 2006), and Phalaenopsis amabilis (Chen and Chang, 2006). Within the Solanacea family, it has been reported for $N$. tobacum (Gill and Saxena, 1993; Stolarz et al., 1991); L. esculentum (Gill et al., 1995; Newman et al., 1996), S. tuberosum (De García and Martínez, 1995; Gill and Saxena, 1993; Kumar and Millam, 2004; Pretova and Dedicova, 1992); and S. melongena (Tarré et al., 2004). However, there are a few reports on the genus Capsicum (Binzel Marla et al., 1996; Harini and Sita, 1993) and all of them on Capsicum annuum L. The objective of this study was to describe the events associated with direct somatic embryogenesis induced from the hypocotyl in $C$. chinense and to determine the structures and tissues of the explant involved in the development of the morphogenetic process through the monitoring of morphological and histological changes during the ontogenesis of the somatic embryo.

\section{Materials and Methods}

Induction of somatic embryogenesis. Somatic embryos of the cultivar BVII-03 of red Habanero pepper ( $C$. chinense) were obtained from hypocotyls segments of 15-dold plantlets from seeds germinated in vitro (Santana-Buzzy et al., 2005). Somatic embryogenesis was induced directly from the explant following the protocol of López-Puc et al. (2006) in a medium containing Murashige and Skoog (1962) mineral salts supplemented with 2,4-dichlorophenoxyacetic acid $(2,4-\mathrm{D} ; 9.05 \mu \mathrm{M})$. The cultures were maintained at $25 \pm 2{ }^{\circ} \mathrm{C}$ with a 16 -h photoperiod $\left(40 \mu \mathrm{mol} \cdot \mathrm{m}^{-2} \cdot \mathrm{s}^{-1}\right)$ during $45 \mathrm{~d}$.

Histological analysis. The embryos took form inside the explant and became visible when a longitudinal cut was made in the hypocotyl epidermis. The somatic embryos were isolated and classified by stages of development (globular, heart-shaped, torpedo-shaped, and cotyledonar). During the process of somatic embryogenesis, biological samples were taken every $24 \mathrm{~h}$ throughout the $45 \mathrm{~d}$ of culture. The samples were placed in 
the fixing solution of formalin acetic alcohol containing $5 \mathrm{~mL}$ of $96 \%$ ethanol, $10 \mathrm{~mL}$ of $37 \%$ formaldehyde, $5 \mathrm{~mL}$ acetic acid, and adjusted to a $100 \mathrm{~mL}$ of volume with distilled water for 24 to $48 \mathrm{~h}$ following the Berlin and Miksche (1976) protocol at $10^{\circ} \mathrm{C}$. After fixing, the samples were dehydrated by successive changes in ethanol solutions at different concentrations $(30 \%, 50 \%, 70 \%, 85 \%, 99 \%$, and $100 \% \mathrm{v} / \mathrm{v})$. Subsequently, after infiltration, the samples were embedded in plastic resin (JB-4 Glycol Methacrilato; Polysciences, Warrington, PA). Serial sections of $5 \mu \mathrm{m}$ were cut off in a rotary microtome HM340E (Microm International $\mathrm{GmbH}$ ), mounted on cytological glass slides, and stained with $0.05 \%$ toluidine blue ( 3 to $5 \mathrm{~min}$ ). Observations and images were obtained with an inverted microscope (Axiovert MC80; Carl Zeiss D-73446).

\section{Results}

Figures 1A and 1B show a longitudinal section of the hypocotyl before being exposed to the culture medium containing 2,4-D. It was possible to distinguish: the cortical parenchyma, characterized by the presence of long, irregular cells of different sizes; the provascular zone had very small cells; and the central zone of the hypocotyl was performed by differentiated xylematic and phloematic elements. The first mitotic activity was observed at $48 \mathrm{~h}$ of culture from the center to outward with the xylem and phloem surrounded by a fine layer of cells that formed the provascular tissue. It can be seen around provascular tissue at the four- to five-cell layer of cortical parenchyma. After $2 \mathrm{~d}$ of culture with 2,4-D, an intense cell division of the hypocotyl provascular cells was observed in both periclinal and anticlinal directions, resulting in the presentation of slight bulges along the procambium with a radial orientation to the vascular strands (Fig. $1 \mathrm{C}-\mathrm{D})$. These bulges evolved into preglobular embryos after 6 to $7 \mathrm{~d}$ of culture that rapidly turned to the globular stage and only became visible when the epidermis of the hypocotyls was broken by the pressure applied from the inside the explant by the embryos (Fig. 2A-B). A line of tiny embryogenic structures along and around the vascular strands was observed (Fig. 2B). These groups of cells, presumably proembryoids, were individualized and separated from each other by a fine wall identified as the protoderm (Fig. 2C-D); the proembryoids evolved into bipolar and independent structures (Fig. 2E-F). The somatic embryos originated directly from the explant cells, and only the provascular cells were involved in the process, apparently without the intervention of the explant's xylem or epidermis cells (Fig. 2C-D). The proembryoids showed an apical region of very small cells with a very dense, stained cytoplasm as well as protodermis and suspensor (Fig. 2C). The suspensor, unlike the protodermis, showed long vacuolated cells with a slightly stained
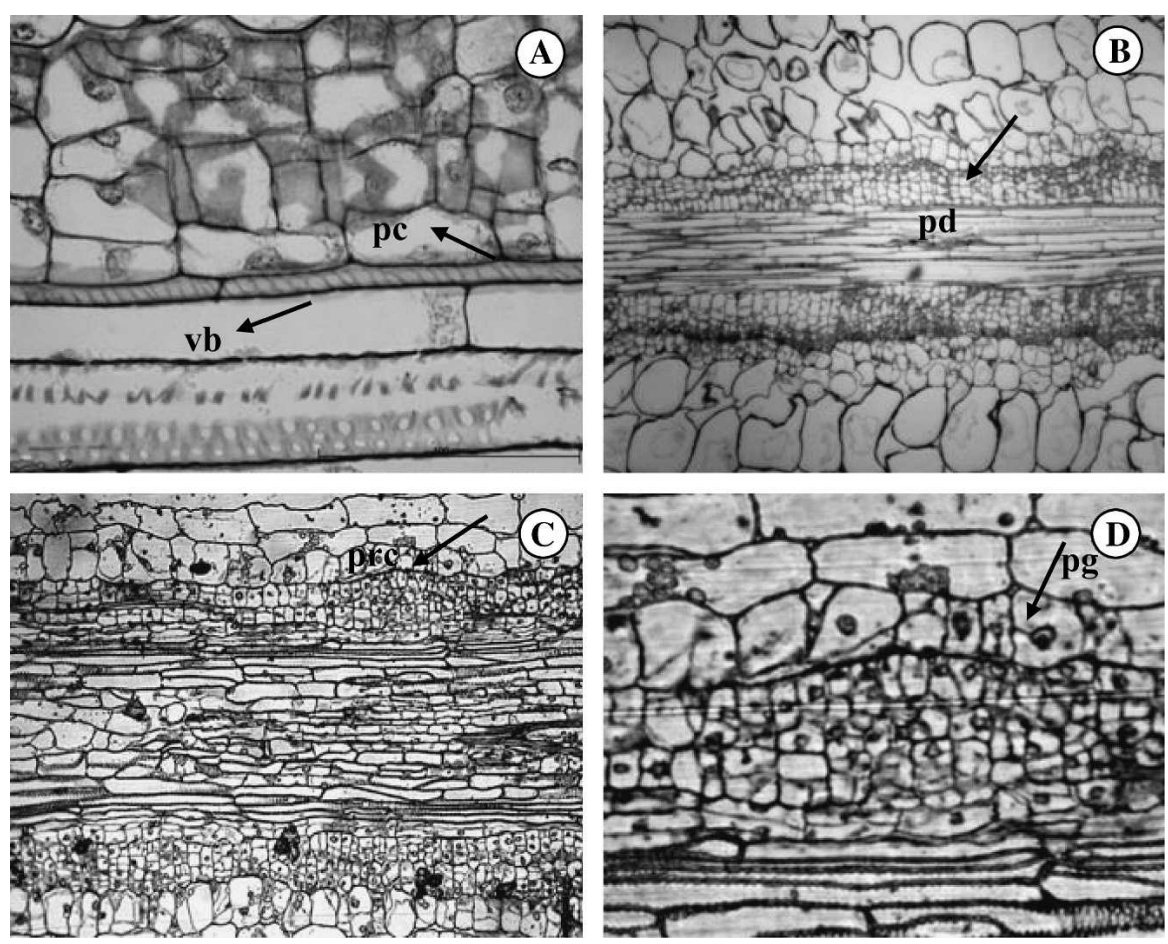

Fig. 1. (A) Longitudinal section of the hypocotyl before in vitro culture (vb = vascular bundles; $\mathrm{pc}=$ parenchymatic cells); (B) longitudinal section showing periclinal cell divisions (pd); (C) longitudinal section of the hypocotyl showing thickening in the procambium (prc) as a result of intense mitotic activity of the provascular cells; (D) longitudinal section showing a cluster of mitotically active cells (pg = proembryonic globules).
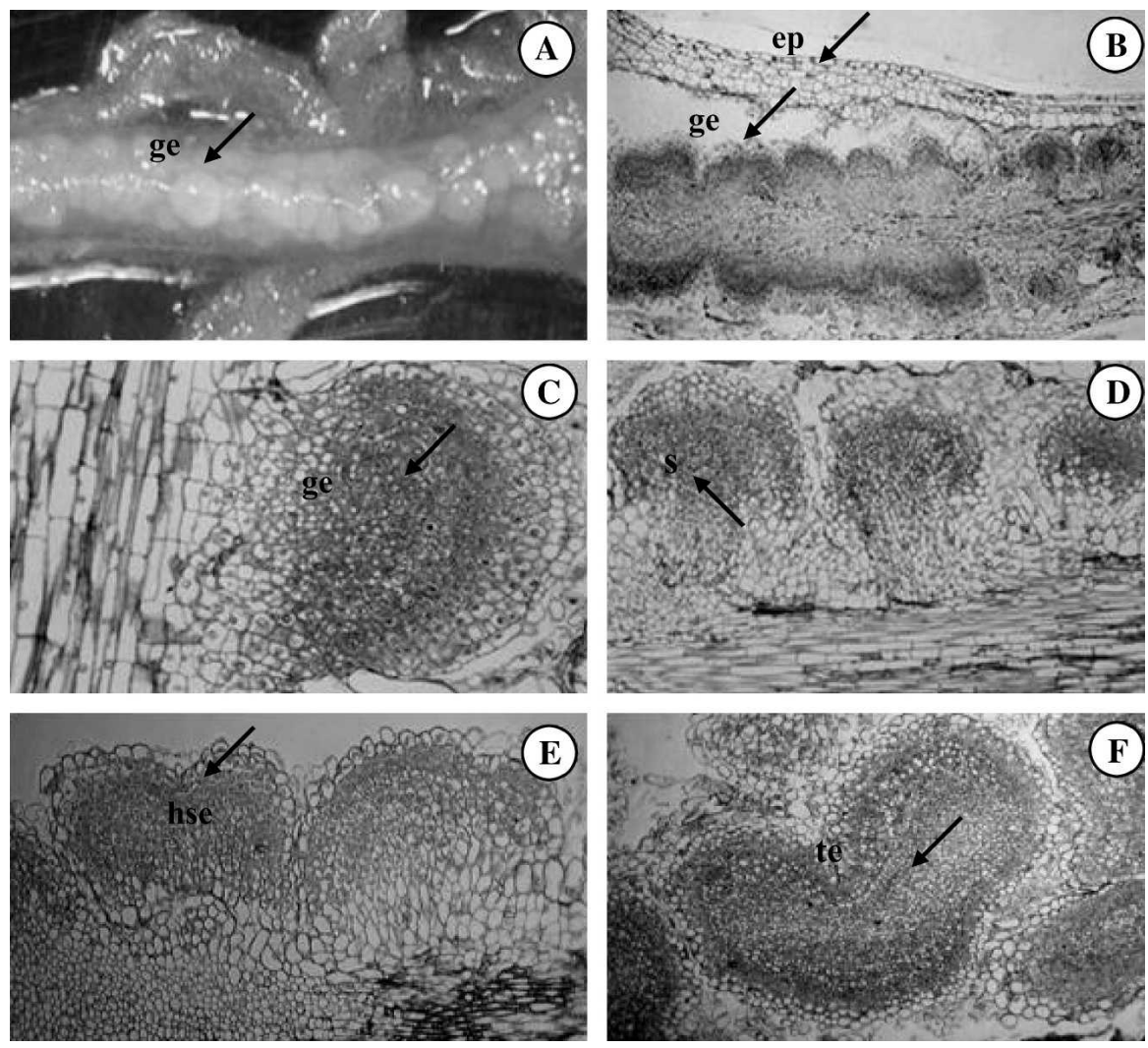

Fig. 2. Ontogenesis of the somatic embryogenesis. Longitudinal section of: (A) segment of hypocotyl with irregular epidermis because of the pressure of the embryos born inside (ge = globular embryo); (B) longitudinal section of the explant during ontogenesis of the somatic embryos in the provascular zone of the hypocotyl (ep = epidermis); (C-D) embryos in early stages of their development (proembryoids). The suspensor formed through successive divisions of the base cells ( $\mathrm{s}=$ suspensor); (E-F) somatic embryos in different stages of development (hse = heart-shaped embryos; te = torpedo embryos). 
cytoplasm (Fig. 2C). After $12 \mathrm{~d}$ of culture induction, a procambium in the alveolated and polarized-shaped embryo was observed. The longitudinal section of the explant (Figs. 2E-F) showed embryos in heart-shaped and torpedo stages, respectively. These perfectly bipolar structures, once formed, did not show a vascular connection with the hypocotyl cells. The bilateral symmetry of somatic embryos was observed in later stages of development.

The transition of proembryoids to preglobular and globular stages (early stages) was characterized by the formation of concentric rings of cells with a small vacuole and a prominent cytoplasm (Fig. 3A). In these meristematic centers, intense mitotic activity was observed (Fig. 3B). The subsequent cellular division in anticlinal and periclinal directions gave rise to meristematic centers consisting of small embryogenic cells with dense cytoplasm, small nucleus, and with small starch grains (Fig. 3A-B). A complex of cells around the embryogenic mass was perfectly distinguishable, producing small masses or isolated zones identified as proembryogenic structures (Fig. 3C-D). The appearance of globular structures was coupled with the development of the protoderm, the outermost layer of a developing embryo (Fig. 3E-F). The protoderm was distinguished in the early globular stages, but it was better defined in the late globular stage (Fig. 3G). A marked reduction in the mitotic activity of the cells and a well-defined cell organization at later stages of the embryos' development were observed, but differentiation did not occur; this event was observed mainly in cells located inside the cellular mass. It was evident by the presence of small vacuolated cells.
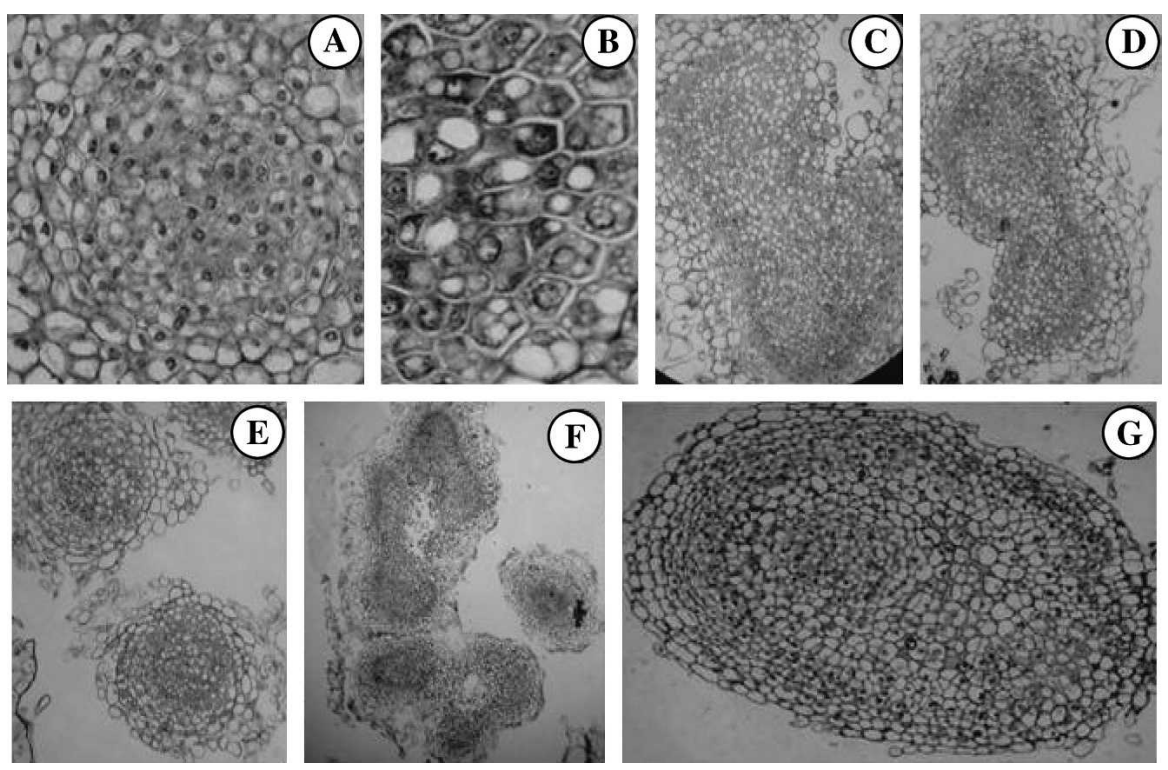

Fig. 3. (A) Presence of a ring of cells with small vacuole and prominent cytoplasm during the formation of the somatic embryo (preglobular); (B) Intense mitotic activity of the cells; (C-D) preglobular embryos; (E-F) globular embryos without vascular connection to the explant; (G) embryo in late globular polarized stage.

Somatic embryos preceded toward the different development stages: globular (Fig. 4A), heart-shaped (Fig. 4B), torpedo (Fig. 4C), and cotyledonar (Fig. 4D-E). The globular stage was followed by the appearance of cotyledonary zones, indicating the heartshaped stage (Fig. 4C). Most of the mature somatic embryos showed bilateral symmetry and typical histology (Fig. 4E). The apical and root meristems and provascular strands of the embryos were clearly visible and displayed characteristic, intense staining the cotyledonary root pole was developed in group of cells with dense cytoplasm (Fig. 4G). Vascular connections between somatic embryos and explants were never observed. The apical meristem of mature somatic embryos in most of the cases was concave in the longitudinal section and composed of two to three cell layers (Fig. 4G), and the root meristem was covered by large cells with starch grains, a typical feature of the root cap (Fig. 4H). In a longitudinal section, tissues observed consisted of protodermis, parenHowever, yet, a high frequency of somatic embryos did not reach the plantlet stage despite the rapid emission of the radicle. This behavior is most likely associated with some physiological or genetic factors and undoubtedly confirms the recalcitrance of $C$. chinense to in vitro regenthe same way as other species of high frequency of deformed somatic embryos, including deformed cotyledons (Fig. $5 \mathrm{~A}-\mathrm{E}$ ), abnormalities in the histodiferentiation of the apical meristem (Fig. 5F), absence of cotyledons (Fig. 5G-H) and the fusion of be a common phenomenon as in other species

HortScience Vol. 44(1) February 2009 of the Capsicum genus. The persistence of this behavior in Habanero pepper also contributes to a marked reduction in the rates of germination and conversion of somatic embryos into normal plants.

The results indicated that we have achieved a direct somatic embryogenesis, in which the embryos evolve normally through the different stages of development. Most of the embryos have bilateral symmetry, provascular tissue along the axis of the embryo, and both apexes (caulinar and apical) easily distinguishable and well defined. This is one of the most complete studies carried out on the origin and ontogenesis of somatic embryos in the genus Capsicum, and it is the first report on the species Capsicum chinense. However, although it provides information of great importance for understanding the origin and evolution of the morphogenesis in this genus, further studies are required to shed light on the origin and nature of this phenomenon affecting the conversion of the embryos of this species of Capsicum into plants. Nevertheless, the results do allow us to infer that the inability of the embryos of Habanero pepper to convert into plants is not related to the ontogenesis of the embryo, but may be caused by genetic factors associated with the genus Capsicum.

\section{Discussion}

The culture of $C$. chinense hypocotyl in a solid medium supplemented with $2,4-\mathrm{D}$ promoted the formation of somatic embryos in high frequency directly from the explant cells (López-Puc et al., 2006). However, to date, there are no reports on studies carried out on this species related to the ontogeny of the somatic embryo development or the cells that acquire the embryogenic competence during the ontogenesis of the somatic embryo. With the results of this anatomical study during induction and development of somatic embryogenesis of $C$. chinense, it was possible to identify the hypocotyl cells with the capacity and predisposition for direct formation of somatic embryos. It was also evident how these competent embryogenic cells evolved up to the formation of the somatic embryo. Although these two events are the most important in somatic embryogenesis, they are the least understood. Kwaaitaal and De Vries (2007), working with Arabidopsis, determined that the gene SERK1 (somatic embryogenesis receptor kinase 1), which was originally identified as a marker for embryogenic competent cells in plant tissue culture, was expressed in procambium cells and in immature vascular cells. The anatomical analysis revealed that in $C$. chinense, the embryos originated from the procambium cells, whereas the cortical parenchyma and epidermal cells did not participate in the process, at least not directly; this agrees with the results of Kwaaitaal and De Vries (2007). In plants, somatic embryos can develop from a competent cell (Nomura and Komamine, 1985); however, the origin of these cells is still uncertain. Many reports state that the 

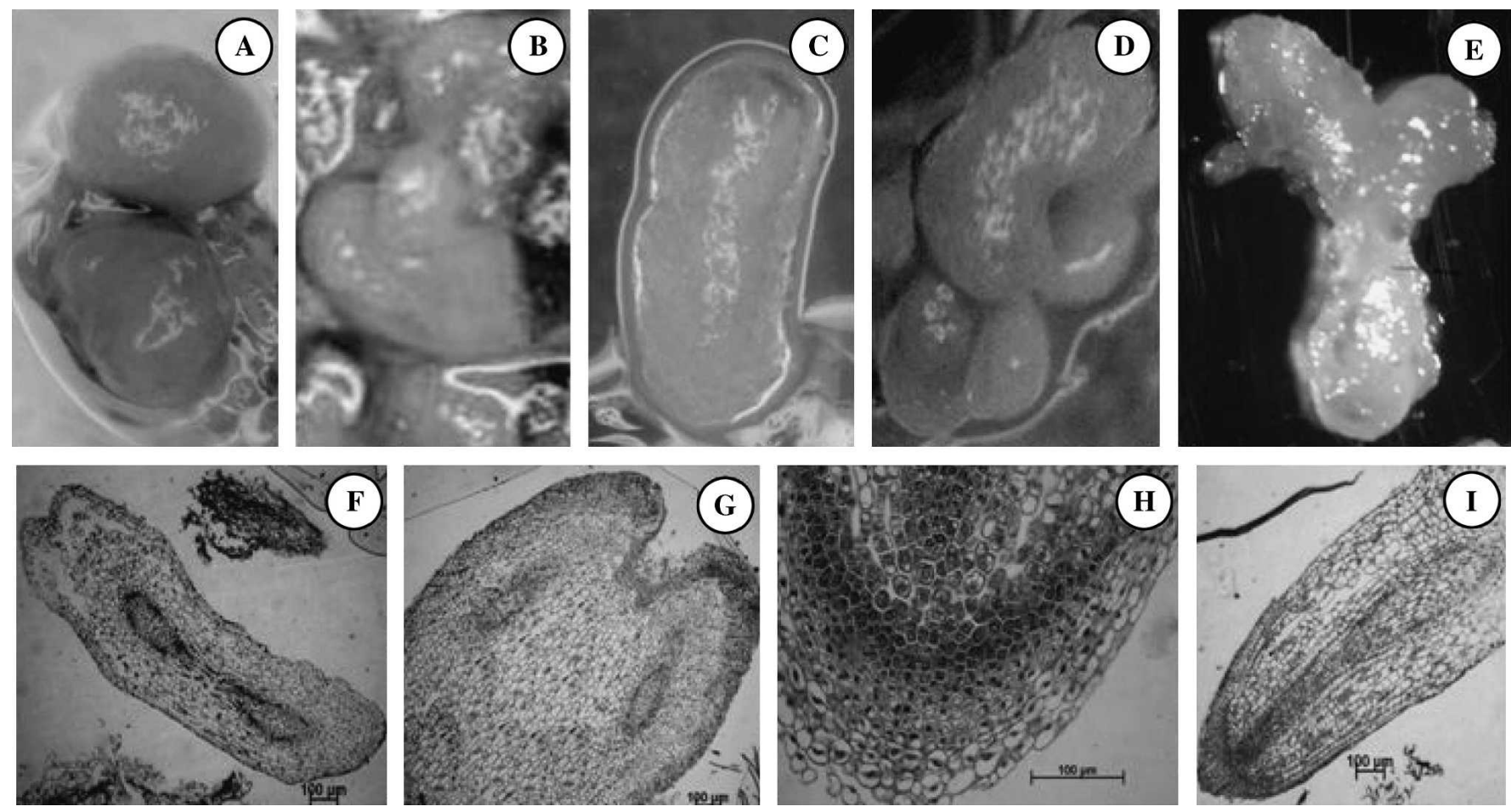

Fig. 4. Different somatic embryo development stages of C. chinense: (A) globular; (B) heart-shaped; (C) torpedo; (D) early cotyledonary; (E) late cotyledonary Longitudinal section of the cotyledonary embryo C. chinense: (F) complete embryo; (G) caulinar apex; (H) radical apex; (I) vascular tissue developed.
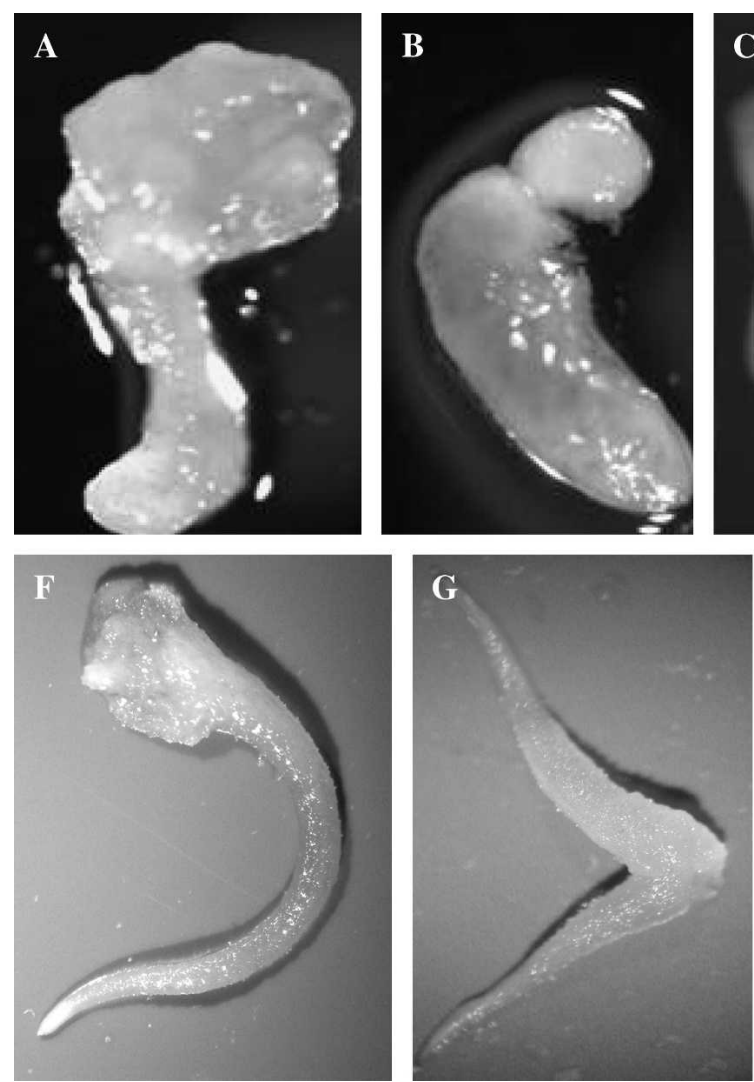
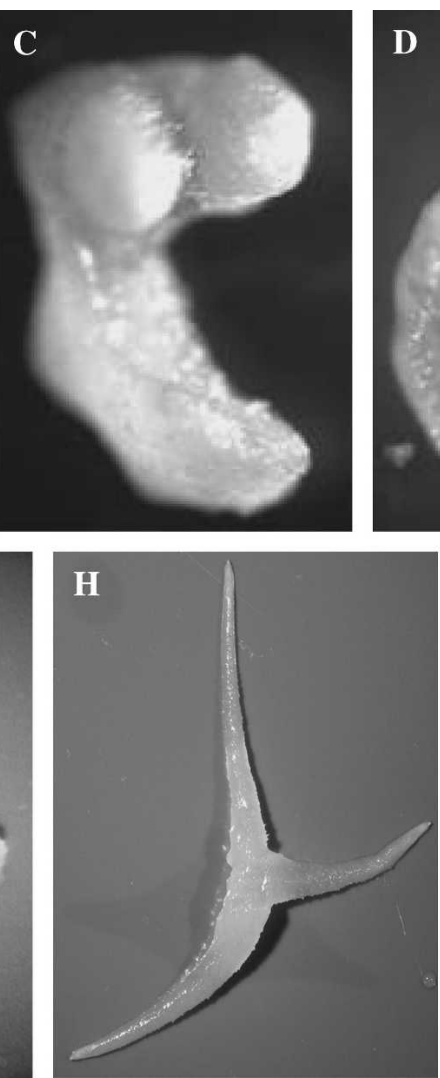
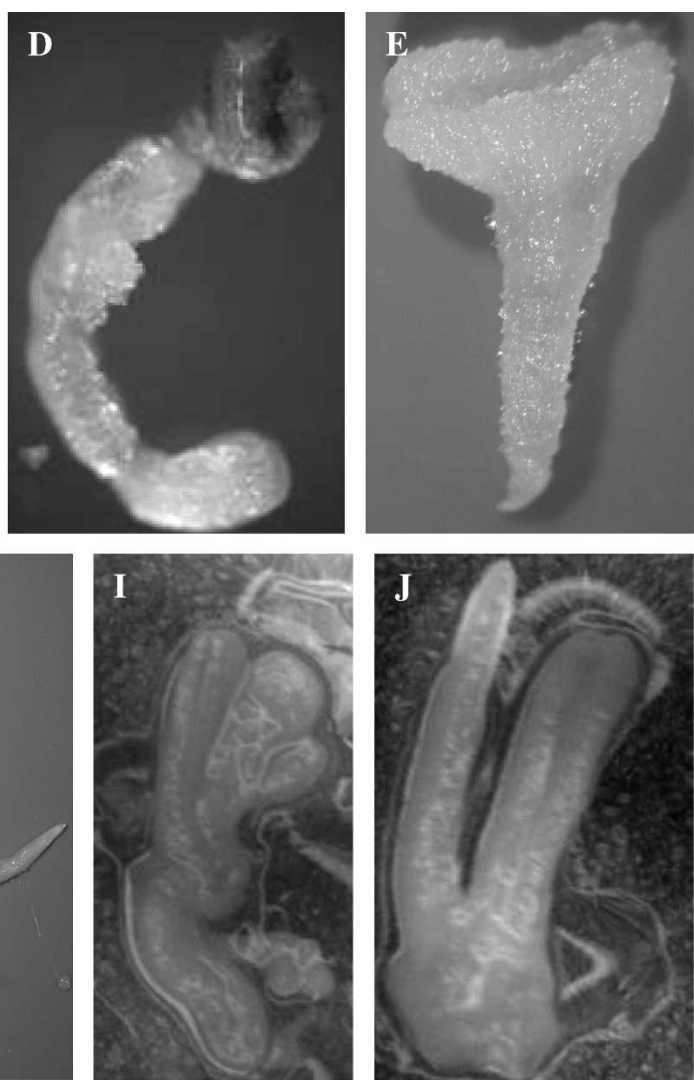

Fig. 5. Abnormalities observed in high frequency during the somatic embryo development of $C$. chinense: Deformed cotyledons (A-E); abnormalities in the histodifferentiation of the apical meristem $(\mathbf{F})$; absence of cotyledons $(\mathbf{G}-\mathbf{H})$; fusion of embryos $(\mathbf{I}-\mathbf{J})$.

totipontence is not an intrinsic property of all plant cells but can be acquired when the explant is exposed to potent synthetic auxins such as the 2,4-D (De Vries et al., 1988;
Mordhorst et al., 1998). Similar studies have been conducted on other species (BespalhokFilho and Hattori, 1997; Guerra and Handro, 1998; Ho and Vasil, 1983; Hutchinson et al.,
1997; Laparra et al., 1997; Ozias-Akins and Vasil, 1982; Sagare et al., 1995; Van Hengel et al., 1998), some of them over periods of up to 40 to $60 \mathrm{~d}$ (Schwendiman et al., 1988; 
Thomas et al., 1972), whereas Masuda et al. (1995), by anatomical analysis of samples, saw somatic embryo formation only from the epidermal cells of explants of carrot hypocotyl.

Somatic embryogenesis from the hypocotyl has been reported in Genciana cruciata (Mikula et al., 2005); Gossypium hirsutum (U1, 2005); Cicer arietinum; Lilium martagon (Kedra and Bach, 2005); Daucus carota (De Vries et al., 1988; Guzzo et al., 1994; Kikuchi et al., 2006; Masuda et al., 1995; Nishiwaki et al., 2000), whereas in the genus Capsicum, only $C$. chinense has presented this regeneration model (López-Puc et al., 2006; Zapata-Castillo et al., 2007). In the case of $C$. annuum, somatic embryos have been obtained only from zygotic embryos in direct and indirect ways (Binzel Marla et al., 1996; Buyukalaca and Mavituna, 1996; Harini and Sita, 1993; Steinitz et al., 2003). We described the specific features of the origin and development of somatic embryos in C. chinense belonging to a genus (Capsicum) known for its recalcitrance to the morphogenesis in vitro. To date, there is no clear evidence of how this process took place. However, all the species of this genus in which somatic embryogenesis has been reported have one problem in common (Binzel Marla et al., 1996; Buyukalaca and Mavituna, 1996; Harini and Sita, 1993; López- Puc et al., 2006; Steinitz et al., 2003; Zapata-Castillo et al., 2007); once the somatic embryos are formed, directly and/or indirectly, most of them become deformed and do not reach the later stages of development (torpedo and cotyledonar). Steinitz et al. (2003) found that the most frequent deformations of the somatic embryos can be classified into three categories: 1) fusion of embryos (Benelli et al., 2001; Carraway and Merkle, 1997; Rodríguez and Wetzstein, 1994; Stipp et al., 2001; Tomaz et al., 2001); 2) absence of cotyledons, only one cotyledon, or deformed cotyledons (Carraway and Merkle, 1997; Jayasankar et al., 2002); 3) anomalies in the histodifferentiation of the apical meristem (Chengalrayan et al., 2001; Jayasankar et al., 2002; Nickle and Yeung, 1993; Padmanabhan et al., 1998; Stipp et al., 2001; Suhasini et al., 1994). This phenomenon could be provoked by genetic, epigenetic, or physiological factors. The permanent exposition of the somatic embryos of Habanero pepper to 2,4-D during induction and throughout their development could be one of the reasons of the mentioned abnormalities. Similar results were reported by Christou and Yang (1989), when their embryogenic cultures were maintained in synthetic auxin for long periods of time. Santos et al. (1997), in an ontogeny study of the somatic embryos from immature cotyledons of soybean [ $G l y$ cine $\max (\mathrm{L}$.) Merr.], described numerous abnormal histodifferentiated embryos like torpedo-like embryos resembling a trumpet. This kind of embryos had well-defined procambium, but neither an apical meristem nor a root meristem was detected. Fernando et al. (2002) found soybean trumpet embryos with normal root meristem, but the shoot meristem was absent. The analysis of histological sections in mature trumpet embryos in peanuts showed a poorly developed meristematic region and low conversion rate (Wetzstein and Baker, 1993) like in soybean (Buchheim et al., 1989, Fernando et al., 2002; Kiss et al., 1991). High frequency of abnormal embryos of Capsicum annuum in later stages has been reported restricting germination and conversion into plants (Steinitz et al., 2003). Thus, the removal of the somatic embryos from the auxin-containing medium must be crucial to normal cotyledon development. However, the Habanero pepper explants only responded to the somatic embryogenesis when they were maintained in a medium containing 2,4-D throughout the whole process of histodifferentiation. The histological analysis showed that, after maturation, the fused embryos developed into fasciated cotyledonary embryos. These fused embryos also showed an epidermal layer common to all of them.

The results showed not only the nature of the hypocotyl cells from which the somatic embryos of Habanero pepper originated, but also the phases through which the embryo passes during its development. These results also represent an important contribution toward a better understanding of morphogenesis of recalcitrant species to in vitro plants regeneration not only for the Capsicum genus, but also for many other similar species affected by this phenomenon.

\section{Literature Cited}

Al-Dein, E., A. Ramamneh, S. Sriskandarajah, and M. Sere. 2006. Plant regeneration via somatic embryogenesis in Schlumbergera truncata. Plant Cell. Tiss. and Org. Cult. 84:333-342.

Alemano, L., M. Bethouly, and N. Michaux-Ferriére. 1996. Histology of somatic embryogenesis form floral tissues of cocoa. Plant Cell Tissue Organ Cult. 46:187-194.

Auboiron, E., M.P. Carron, and N. MichauxFerriere. 1990. Influence of atmospheric gases, particularly ethylene, on somatic embryogenesis of Hevea brasiliensis. Plant Cell Tissue Organ Cult. 21:31-37.

Benelli, C., A. Fabbri, S. Grassi, M. Lambardi, and E. Rugini. 2001. Histology of somatic embryogenesis in mature tissues of olive (Olea europaea L.). J. Hort. Sci. Biotechnol. 76:112-119.

Berlin, G.P. and J.P. Miksche. 1976. Botanical microtechnique and cytochemistry. 3rd Ed. Iowa State University Press, Ames, IA.

Bespalhok-Filho, C.J. and K. Hattori. 1997. Embryogenic callus formation and histological studies from Stevia rebaudiana (Bert.) Bertoni floret explants. Rev. Bras. Fisiol. Vegetal 9:185-188.

Binzel Marla, L., N. Sankhla, S. Joshi, and D. Sankhla. 1996. Induction of direct somatic embryogenesis and plant regeneration in pepper (Capsicum annuum L.). Plant Cell Rpt. 15:536-540.

Buchheim, J.A., S.M. Colburn, and J.P. Ranch. 1989. Maturation of soybean somatic embryo and the transition to plantlet growth. Plant Physiol. 89:768-775.

Buyukalaca, S. and F. Mavituna. 1996. Somatic embryogenesis and plant regeneration of pepper in liquid media. Plant Cell Tissue Organ Cult. 46:227-235.
Cangahuala-Inocente, G.C., N. Steiner, M. Santos, and M.P. Guerra. 2004. Morphohistological analysis and histochemistry of Feijoa sellowiana somatic embryogenesis. Protoplasma 224:33-40.

Carrawar, D. and S. Merkle. 1997. Plantlet regeneration from somatic embryos of American chestnut. Can. J. For. Res. 27:1805-1812.

Chen, J.T. and W.C. Chang. 2006. Direct somatic embryogenesis and plant regeneration from leaf explants of Phalaenopsis amabilis. Biol. Plant. 50:169-173.

Chengalrayan, K., S. Hazra, and M. GalloMeagher. 2001. Histological analysis of somatic embryogenesis and organogenesis induced from mature zygotic embryo-derived leaflets of peanut (Arachis hypogaea L.). Plant Science 161:415-421.

Christou, P. and N.S. Yang. 1989. Developmental aspects of soybean (Glycine max) somatic embryogenesis. Ann. Bot. (Lond.) 64:225-234.

Decout, E., T. Dubois, M. Guedira, J. Dubois, J.C. Audran, and J. Vasseur. 1994. Role of temperature as a triggering signal for organogenesis or somatic embryogenesis in wounded leaves of chicory cultured in vitro. J. Expt. Bot. 45:18591865.

De García, E. and S. Martínez. 1995. Somatic embryogenesis in Solanum tuberosum L. cv. Desirée from ítem nodal sections. J. Plant Physiol. 145:526-530.

De Jong, A.J., E.D.L. Schimidt, and S.C. De Vries 1993. Early events in higher plants embryogenesis. Plant Mol. Biol. 22:367-377.

De Vries, S., H. Booij, H. Meyerink, G. Huisman, D. Wilde, T. Tomas, and A. Van Kammen. 1988. Acquisition of embryogenic potential in carrot cell-suspensions cultures. Planta 176:196-204.

Fernando, J.A., M.L.C. Vieira, I.O. Geraldi, and B. Appezzato-da-Gloria. 2002. Anatomical study of somatic embryogenesis in Glicine max (L.) Merril. Brazilian Archives of Biology and Technology. 45:277-286.

Fransz, P.F. and J.H.N. Schel. 1991. An ultrastructural study on the development of Zea mays somatic embryos. Can. J. Bot. 69:858-865.

Garin, E., E. Grenier, and G. Grenier de March. 1997. Somatic embryogenesis in wild cherry (Prunus avium). Plant Cell Tissue Organ Cult. 48:83-91

Gill, R., K. Malik, H. Sanago, and P. Saxena. 1995. Somatic embryogenesis and plant regeneration from seedling cultures of tomato (Lycopersicon esculentum Mill). J. Plant Physiol. 147:273-276.

Gill, R. and P. Saxena. 1993. Somatic embryogenesis in Nicotiana tabacum L.: Induction by thidiazuron of direct embryo differentiation from cultures leaf discs. Plant Cell Rpt. 12:154-159.

Goh, D.K.S., N. Michaux-Ferriére, O. Monteuuis, and M.C. Bon. 1999. Evidence of somatic embryogenesis from root tip explants of the rattan Calamus manan. In Vitro Cell. Dev. Biol. Plant 35:424-427.

Guerra, M.P. and W. Handro. 1998. Somatic embryogenesis and plant regeneration in different organs of Euterpe edulis Mart. (Palmae): Control and structural features. J. Plant Res. 111:65-71.

Guzzo, F., B. Baldan, P. Mariani, F. Lo Schiavo, and M. Terzi. 1994. Studies on the origin of totipotent cells in explants of Daucus Carota L. J. Expt. Bot. 45:1427-1432.

Halperin, W. 1966. Alternative morphogenetic events in cell suspensions. Amer. J. Bot. 53:443-453.

Harini, I. and G.L. Sita. 1993. Direct somatic embryogenesis and plant regeneration from immature embryos of chili (Capsicum annuum L.). Plant Sci. 89:107-112.

Ho, W.J. and I.K. Vasil. 1983. Somatic embryogenesis in sugarcane (Saccharum officianarum 
L.). I. The morphology and physiology of callus formation and the ontogeny of somatic embryos. Protoplasma 118:169-180.

Hutchinson, M.J., S. KrishnaRaj, and P.K. Saxena. 1997. Inhibitory effect of GA3 on the development of thidiazuron-induced somatic embryogenesis in geranium (Pelargonium $\times$ hortorum Bailey) hypocotyls cultures. Plant Cell Rpt. 16:435-438.

Jayansakar, S., B. Bondada, Z. Li, and D. Gray. 2002. A unique morphotype of grapevine somatic embryos exhibits accelerated germination and early plant development. Plant Cell Rpt. 20:907-911.

Kedra, M. and A. Bach. 2005. Morphogenesis of Lilium martagon. explants in callus culture. Acta Biol. Cracov. Ser.; Bot. 47:65-73.

Kikuchi, A., N. Sanuki, K. Higashi, T. Koshiba, and H. Kamada. 2006. Abscisic acid and stress treatment are essential for the acquisition of embryogenic competence by carrot somatic cells. Planta 223:637-645.

Kiss, E., L.E. Heszky, G. Gyulai, H.S. Horváth, and A. Csillag. 1991. Neomorph and leaf differentiation as alternative morphogenetic pathways in Soybean tissue culture. Acta Biol. Hung. 42:313-321.

Kumar, S. and S. Millam. 2004. Somatic embryogenesis in Solanum tuberosum L.: A histological examination of key developmental stages. Plant Cell Rpt. 23:115-119.

Kwaaitaal, M.A.C.J. and S.C. De Vries. 2007. The SERK1 gene expressed in procambium and immature vascular cells. J. Expt. Bot. 58:28872896.

Laparra, H., R. Bronner, and G. Hahne. 1997. Histological analysis of somatic embryogenesis induced in leaf explants of Helianthus smithii. Heiser. Protoplasma 196:1-11.

Lee, K., K. Zapata, H. Brunner, and R. Afza. 1997. Histology of somatic embryo initiation and organogenesis from rhizome explants of Musa spp. Plant Cell Tissue Organ Cult. 51:1-8.

Loiseau, J., N. Michaux Ferriére, and Y. Le Deunff. 1998. Histology of somatic embryogenesis in pea. Plant Physiol. Biochem. 36:683-687.

López-Puc, G., A. Canto-Flick, L. Iglesias-Andreu, F. Barredo-Pool, P. Zapata-Castillo, M. MontalvoPeniche, F. Barahona-Pérez, and N. SantanaBuzzy. 2006. Direct somatic embryogenesis: A highly efficient protocol for in vitro regeneration of Habanero pepper (Capsicum chinense Jacq.). HortScience 41:1-7.

Lu, C. and I.K. Vasil. 1985. Histology of somatic embryogenesis in Panicum maximum (Guinea grass). Amer. J. Bot. 72:1908-1913.

Mandal, A.K.A. and D. Gupta. 2003. Somatic embryogenesis of safflower: Influence of auxin and ontogeny of somatic embryos. Plant Cell. Tiss. and Org. Cult. 72:27-31.

Marin-Hernández, T., J. Marquez-Guzmán, B. Rodriguez-Garay, and A. Rubluo. 1998. Early stages in the development of somatic embryogenesis in Mammillaria san angelensis 'Sánchez Mejorada' (Cactacea) a severely endangered species. Phyton International Journal of Experimental Botany. 62:181-186.

Masuda, H., S. Oohashi, Y. Tokuji, and Y. Mizue. 1995. Direct embryo formation from epidermal cells of carrot hypocotyls. J. Plant Physiol. 45:531-534.

Menéndez-Yuffá, A. and E. García de García. 1997. Morphogenic events during indirect somatic embryogenesis in coffea 'Catimor'. Protoplasma 199:208-214.

Mikula, A., A. Fiuk, and J. Rybczyñski. 2005. Induction, maintenance and preservation of embryogenic competence of Gentiana Cruciata L. cultures. Acta Biol. Cracov. Ser.; Bot. 47:227-236.
Mordhorst, A.P., K.J. Voerman, M.V. Hartog, E.A. Meijer, J. Van Went, M. Koornneef, and S.C. De Vries. 1998. Somatic embryogenesis in Arabidospsis thaliana is facilitated by mutations in genes repressing meristematics cell divisions. Genetics 149:549-563.

Murashige, R. and F. Skoog. 1962. A revised method for rapid growth and bioassays with tissue cultures. Plant Physiol. 15:473-497.

Navarro, C., R.M. Escobedo and A. Mayo. 1997. In vitro plant regeneration from embryogenesis cultures of a diploid and a triploid, Cavendish banana. Plant Cell Tissue Organ Cult. 51:17-25.

Newman, P., S. Krishnaraj, and P. Saxena. 1996. Regeneration of tomato (Lycopersicum esculentum Mill.): Somatic embryogenesis and shoot organogenesis from hypocotyl explants induced with 6-benziladedine. Intl. J. Plant Sci. 157:554-560.

Nickle, C. and E. Yeung. 1993. Failure to establish a functional shoot meristem may be a cause of conversion failure in somatic embryos of $D$. carota. Am. J. Bot. 80:128-129.

Nishiwaki, M., K. Fujino, Y. Koda, K. Masuda, and Y. Kikuta. 2000. Somatic embryogenesis induced by the simple application of abscisic acid to carrot (Daucus carota L.) seedlings in culture. Planta 211:756-759.

Nomura, K. and A. Komamine. 1985. Identification and isolation of single cells that produce somatic embryos at a high frequency in a carrot suspension culture. Plant Physiol. 79:988-991.

Nonohay, J.S., J.E.A. Mariath, and H. Winge. 1999. Histological analysis of somatic embryogenesis in Brazilian cultivars of barley, Hordeum vulgare L. Poaceae Plant Cell Rpt. 18:929-934.

Ozias-Akins, P. and K.I. Vasil. 1982. Plant regeneration from cultured immature somatic embryos and inflorescences of Triticum aestivum L. (wheat): Evidence for somatic embryogenesis. Protoplasma 110:95-105.

Padmanabhan, K., D. Cantliffe, R. Harrel, and D. McConnell. 1998. A comparison of shoot-forming and non-shoot-forming somatic embryos of sweet potato (I. batatas) using computer vision histological analysis. Plant Cell Rpt. 17:685692.

Pretova, A. and B. Dedicova. 1992. Somatic embryogenesis in Solanum tuberosum L. cv. Dérirée from unripe zygotic embryos. J. Plant Physiol. 139:539-542.

Puigderrajols, P., B. Fernández-Guijarro, M. Toribio, and M. Molinas. 1996. Origin and early development of secondary embryos in Quercus suber L. Intl. J. Plant Sci. 157:674-684.

Rodriguez, A. and H. Wetztein. 1994. The effect of auxin type and concentration on pecan $(C$. illinoinensis) somatic embryo morphology and subsequent conversion in plants. Plant Cell Rpt. 13:607-611.

Sagare, A.P., K. Suhasini, and K.V. Krishnamurthy. 1995. Histology of somatic embryo initiation and development in chickpea (Cicer arietinum L.). Plant Sci. 109:87-93.

Santana-Buzzy, N., A. Canto-Flick, F. BarahonaPérez, M. Montalvo-Peniche, P. Zapata-Castillo, A. Solís-Ruiz, A. Zaldivar-Collí, O. GutierrezAlonso, and M.L. Miranda-Ham. 2005. Regeneration of Habanero pepper (Capsicum chinense Jacq.) via organogenesis. HortScience 40:18291831.

Santos, K.G.B., E. Mundstock, and M.H. Bodanese-Zanettini. 1997. Genotype-specific normalization of soybean somatic embryogenesis through the use of an ethylene inhibitor. Plant Cell Rpt. 16:859-864.

Schwendiman, J., C. Pannetier, and N. MichauxFerriere. 1988. Histology of somatic embryo- genesis from leaf explants of the oil palm Elaeis guineensis. Ann. Bot. (Lond.) 62:43-52. Steinitz, B., M. Küsek, Y. Tabib, I. Paran, and A. Zelcer. 2003. Pepper (Capsicum annuum L.) regenerants obtained by direct somatic embryogenesis fail to develop a shoot. In Vitro Cell. Dev. Biol. Plant 39:296-303.

Stipp, L., B. Mendes, S. Pieded, and A. Rodriguez. 2001. In Vitro morphogenesis of C. melon var. inodorus. Plant Cell Tiss. Org. Cult. 65:81-89.

Stolarz, A., J. Macewicz, and H. Lörz. 1991. Direct somatic embryogenesis and plant regeneration from leaf explants of Nicotiana tabacum L. J. Plant Physiol. 137:347-357.

Stuart, D.A., S.G. Strickland, and K.A. Walker. 1987. Bioreactor production of alfalfa somatic embryos. HortScience 22:800-803.

Suhasini, K., A.P. Sagare, and K.V. Krishnamurthy. 1994. Direct somatic embryogenesis from mature embryo axes in chickpea (Cicer arietinum). Plant Sci. 102:189-194.

Svobodová, H., J. Albrechtova, L. Kumstyrova, H. Lipavska, M. Vagner, and Z. Vondrakova. 1999. Somatic embryogenesis in Norway spruce: Anatomical study of embryo development and influence of polyethylene glycol on maturation process. Plant Physiol. Biochem. 37:209-221.

Tarré, E., C. Magioli, M. Margis-Pinheiro, G. Sachetto-Martins, E. Mansur, and L. SantiagoFernandes. 2004. In vitro somatic embryogenesis and adventitious root initiation have a common origin in eggplant (Solanum melongena L.). Revista Brasil. Bot. 27:79-84.

Thomas, E., N.R. Konar, and E.H. Street. 1972. The fine structure of the embryogenic callus of Ranuculus sceleratus L. J. Cell Sci. 2:95-109.

Tomaz, M., B. Mendes, F. Filho, C. Demetrio, N. Jansakul, and A. Rodriguez. 2001. Somatic Embryogenesis in Citrus spp.: Carbohydrate stimulation and histodifferentation. In vitro Cell. Dev. Biol. Plant. 37:446-452.

Toonen, M.A.J., T. Hendriks, Ed. D.L. Schmidt, H.A. Verhoeven, A. Kammen, and S.C. De Vries. 1994. Description of somatic-embryoforming single cells in carrot suspensions cultures employing video cell tracking. Planta 194:565-572.

U1, I. 2005. Callus proliferation and somatic embryogenesis in cotton (Gossypium hirsutum L.). Afr. J. Biotechnol. 4:206-209.

Van Hengel, A., F. Guzzo, A. Van Kammen, and S.C. De Vries. 1998. Expresión pattern of the carrot EP3 endochitinase gene in suspensions cultures and in developing seeds. Plant Physiol. 117:43-53.

Wetzstein, H.Y. and C.M. Baker. 1993. The relationship between somatic embryo morphology and convertion in peanut (Arachis hypogaea L.). Plant Sci. 92:81-89.

Williams, E.G. and G. Maheswaran. 1986. Somatic embryogenesis: Factors influencing coordinated behaviour of cells as an embryogenic group. Ann. Bot. (Lond.) 57:443-462.

Yeung, E.C., M.H. Rahman, and T.A. Thorpe. 1996. Comparative development of zygotic and microspore-derived embryos in Brassica napus L. cv. Topas. I. Histodifferentiation. Intl. J. Plant Sci. 157:27-39.

Zapata-Castillo, P.Y., A. Canto-Flick, G. LópezPuc, A. Solís-Ruiz, F. Barahona-Pérez, L. Iglesias-Andreu, and N. Santana-Buzzy. 2007. Somatic embryogenesis in Habanero pepper (C. chinense Jacq.) from cell suspensions. HortScience 42:329-333.

Zegzouti, R., M. Arnould, and J. Favre. 2001. Histological investigation of the multiplication step in secondary somatic embryogenesis of Quercus robur L. Ann. For. Sci. 58:681-690. 